Daniel Gaido, Paul Levi y los orígenes del comunismo alemán: el KPD y las raíces de la política de Frente Único (enero 1919-marzo 1921) / Paul Levi and the Origins of German Communism: the KPD and the Roots of the United Front Policy (January 1919-March 1921), Revista Izquierdas.cl, número 22, enero 2015, ISSN 0718-5049, Santiago de Chile, pp. 20-47

\title{
Paul Levi y los orígenes del comunismo alemán: el KPD y las raíces de la política de Frente Único (enero 1919-marzo 1921)
}

\author{
Paul Levi and the Origins of German Communism: the KPD and the Roots of \\ the United Front Policy (January 1919-March 1921)
}

Daniel Gaido*

\begin{abstract}
Resumen
Este trabajo evalúa el accionar político de Paul Levi, el heredero político de Rosa Luxemburg, quien condujo al Partido Comunista alemán (KPD) desde la muerte de Rosa Luxemburg y Karl Liebknecht, en enero de 1919, hasta poco antes del putsch conocido como la "acción de marzo" de 1921, dos años durante los cuales Levi consiguió transformar al KPD en un partido obrero revolucionario de 350.000 miembros. Intentaremos demostrar, mediante el análisis de documentos primarios en alemán e inglés, que la política de Frente Único fue adoptada por la Internacional Comunista a instancias del KPD, cuyo aporte al desarrollo de la táctica de la Internacional Comunista fue enfatizado por el propio Lenin. La comprensión de estos procesos es fundamental para entender la evolución de la revolución alemana, que se extendió desde noviembre de 1918 hasta octubre de 1923, y cuyo fracaso eventual fue la causa última de la degeneración estalinista de la revolución rusa y de la Internacional Comunista.
\end{abstract}

Keywords: Paul Levi, Rosa Luxemburg, Communist Party of Germany (KPD), Communist International (Comintern), German Revolution, United Front

\begin{abstract}
This paper evaluates the political activity of Paul Levi, the political heir of Rosa Luxemburg, who led the German Communist Party (KPD) from the death of Rosa Luxemburg and Karl Liebknecht in January 1919 until shortly before the putsch known as the "March Action" of 1921, two years during which Levi managed to transform the KPD into a revolutionary workers' party with 350,000 members. We will attempt to demonstrate, with the help of primary sources in
\end{abstract}

\footnotetext{
* Argentino, Ph.D. (2000), Universidad de Haifa (Israel), es investigador adjunto del Consejo Nacional de Investigaciones Científicas y Técnicas (CONICET). Es autor de The Formative Period of American Capitalism (London: Routledge, 2006) y co-editor, junto con Richard B. Day, de Witnesses to Permanent Revolution: The Documentary Record (Brill, 2009, Haymarket, 2011) y Discovering Imperialism: Social Democracy to World War I (Brill, 2011, Haymarket, 2012).danielgaid@ gmail.com
} 
German and English, that the United Front policy was adopted by the Communist International at the initiative of the KPD, whose contribution to the development of the tactics of the International Communist was emphasized by Lenin himself. An understanding of these processes is essential for the analysis of the German Revolution, which lasted from November 1918 to October 1923, and whose eventual failure was the ultimate cause of the Stalinist degeneration of the Russian revolution and the Communist International.

Palabras clave: Paul Levi, Rosa Luxemburg, Partido Comunista de Alemania (KPD), Internacional Comunista (Comintern), Revolución alemana, Frente Único

\section{Introducción}

En su libro Moscú bajo Lenin, Alfred Rosmer precisa que en 1920 "el Partido Socialista Italiano y el Partido Comunista Alemán eran, aparte del Partido Comunista Ruso, los dos grandes Partidos de la Internacional Comunista" (Rosmer 1972, p. 80). De hecho, la dinámica de la Internacional durante su "período leninista" (1919-1922) estuvo dictada por la interacción con estos dos grandes partidos, y sería el eventual fracaso de las revoluciones alemana e italiana el que conduciría primero a la "bolchevización" de los Partidos Comunistas por Zinoviev y luego a la transformación de la Internacional en una herramienta de la política exterior soviética por parte de Stalin, hasta su eventual disolución en el marco de la alianza con Estados Unidos y Gran Bretaña en 1943 (Claudín 1978).

El objetivo del presente trabajo es analizar la interacción entre la Internacional Comunista y su sección alemana durante el "período leninista", a fines de analizar los aportes de esta última al desarrollo político de la Internacional. Nuestro "marco teórico" es el marxismo - más específicamente, utilizamos como marco de referencia los trabajos de Pierre Broué sobre la revolución alemana y la Internacional Comunista (Broué 2005 y 1997) ${ }^{1}$ y las colecciones documentales en alemán de Hermann Weber (Weber 1967, 1969, 1973). Nuestra hipótesis central es que la táctica conocida como el Frente Único fue adoptada por la Internacional Comunista a instancias del Partido Comunista Alemán. Intentaremos demostrar asimismo, basándonos en fuentes primarias en alemán, que el heredero político de Rosa Luxemburg, Paul Levi, jugó un rol central en el diseño e implementación de dicha política. El nombre de Paul Levi ha vuelto al debate de los historiadores de izquierdas desde en la publicación en 2011 de sus obras selectas en inglés, editadas por David Fernbach (Levi 2011). Como conclusión de nuestro trabajo ofreceremos

\footnotetext{
${ }^{1}$ La obra central de Broué, Histoire de l'Internationale Communiste, 1919-1943, aún no ha sido traducida al castellano. Su historia de la revolución alemana ha sido traducida solo parcialmente: la edición original abarca hasta el fracaso del "octubre alemán" en 1923, mientras que la edición española se detiene con el fracaso del Levantamiento Espartaquista en enero de 1919 (Broué 1973).
} 
una evaluación de los aportes de dicha obra a la historiografía sobre la revolución alemana y la Internacional Comunista.

\section{La fundación del Partido Comunista de Alemania y el Levantamiento Espartaquista}

La revolución alemana pasó por tres etapas principales desde noviembre de 1918 hasta octubre de 1923. La primera fase se inició en noviembre de 1918, con una serie de eventos que comenzaron con el motín de los marineros de la flota de guerra alemana en Kiel, el colapso del ejército alemán y el fin de la Primera Guerra Mundial, la formación de consejos (Räte: soviets) de delegados de obreros y soldados, la abdicación del Kaiser Guillermo II y la proclamación de la república. Un Congreso Nacional de Consejos de Trabajadores y Soldados (Reichskongress der Arbeiter- und Soldatenräte), celebrado del 16 al 21 diciembre de 1918, se disolvió después que el líder del Partido Socialdemócrata Alemán (Sozialdemokratische Partei Deutschlands, SPD), Friedrich Ebert, lo persuadiera de entregar el poder a un gobierno provisional burgués, irónicamente llamado, según el ejemplo soviético, Consejo de Comisarios del Pueblo (Rat der Volksbeauftragten). A este último organismo también perteneció, hasta el 29 de diciembre de 1918, el Partido Socialdemócrata Independiente de Alemania (Unabhängige Sozialdemokratische Partei Deutschlands, USPD), una escisión centrista y pacifista del SPD creada en abril de 1917, que originalmente incluía también a la Liga Espartaco (Spartakusbund) liderada por Rosa Luxemburg y Karl Liebknecht.

El Congreso fundacional del Partido Comunista de Alemania (Liga Espartaco), el KPD(S) - Kommunistische Partei Deutschlands (Spartakusbund) -, que tuvo lugar luego de la escisión de la Liga Espartaquista del USPD, se llevó a cabo desde el 30 de diciembre de 1918 al $1^{\circ}$ de enero de 1919. En este congreso, y a instancias de Rosa Luxemburg, Paul Levi dio un discurso abogando por la participación del $\operatorname{KPD}(\mathrm{S})$ en las elecciones a la Asamblea Nacional Constituyente que redactaría la Constitución de Weimar - no por albergar ilusiones parlamentarias, sino con el fin de llegar a los trabajadores con un mensaje que rompiera con el consenso contrarrevolucionario en torno a una república democrático- burguesa como alternativa al movimiento de los consejos que entonces sacudía a Alemania. El congreso fundacional del $\operatorname{KPD}(\mathrm{S})$ lamentablemente rechazó esta posición, condenándose al aislamiento político en un momento crucial en la historia de Alemania y del mundo (ver la versión inglesa del discurso de Levi en Fernbach 2011, pp. 35-42).

Cuatro días después, el 5 de enero de 1919, el abortado Levantamiento Espartaquista (Spartakusaufstand) en Berlín resultó en el asesinato de Rosa Luxemburg y Karl Liebknecht, el 15 de enero de 1919, por bandas paramilitares (Freikorps). Fue como resultado de esta tragedia, que decapitó al $\mathrm{KPD}(\mathrm{S})$, que su liderazgo político pasó a manos de Paul Levi, como heredero político de Rosa Luxemburg - una posición que nunca buscó ocupar, sino que le fue impuesta por las circunstancias históricas.

Cuatro días después, el 19 de enero 1919, se llevaron a cabo las elecciones a la Asamblea Constituyente, que se reuniría en Weimar, una ciudad provinciana retirada de la 
agitación revolucionaria de la capital. Esta Asamblea confirmó la posición de Ebert como Reichspräsident.

Un efecto secundario del Levantamiento Espartaquista fueron la serie de revueltas conocidas como la República Soviética de Baviera o de Múnich (Münchner Räterepublik), que estallaron entre el 7 de abril y 2 de mayo de 1919, y que culminaron en el breve régimen comunista liderado por Eugen Leviné y Max Levien. La represión de la República Soviética bávara, que cerró la primera fase de la revolución alemana, convirtió a Múnich en un caldo de cultivo para todo tipo de organizaciones de extrema derecha, incluyendo el Nationalsozialistische Deutsche Arbeiterpartei (NSDAP) de Adolf Hitler.

La firma del Tratado de Versalles el 28 de junio de 1919, con sus duras imposiciones en Alemania, y la aprobación un mes después de la Constitución de Weimar, contribuyeron aún más a la identificación, en los círculos de derecha, de la república de Weimar con la humillación nacional y las penurias económicas.

\section{Paul Levi y las “Tesis de Heidelberg” (24 de octubre de 1919)}

Entre el 20 y el 24 de octubre de 1919 el $\operatorname{KPD}(\mathrm{S})$ celebró su segundo Congreso en Heidelberg, que expulsó a la tendencia anarcosindicalista de ultra-izquierda agrupada en torno a Heinrich Laufenberg y Fritz Wolffheim en Hamburgo - un grupo que más tarde gravitaría hacia el partido nazi. Dicho congreso aprobó, a iniciativa de Paul Levi, las así llamadas "Tesis de Heidelberg," o más propiamente "Tesis sobre los principios y las tácticas comunistas" (Leitsätze über kommunistische Grundsätze und Taktik, ver la versión inglesa de las "Tesis de Heidelberg" en Fernbach 2011, pp. 67-69). Las "Tesis de Heidelberg" constituyeron, en palabras de Pierre Broué, "el primer intento sistemático para asegurar la adopción de los principios y las tácticas de los bolcheviques en Rusia" (Broué 2005, 855). La adopción de estas tesis, que indicaban que el partido no podía renunciar en principio a participar en las elecciones, que llamaban a conformar secciones comunistas en los sindicatos, y que condenaban cualquier tipo de federalismo organizativo como el que predicaba el ala anarco-sindicalista del $\mathrm{KPD}(\mathrm{S})$, llevó a la escisión de dichos elementos para formar el Kommunistische Arbeiterpartei Deutschlands (KAPD) el 3 de abril de 1920. El líder del KAPD, Otto Rühle, afirmó más tarde que las famosas 21 Condiciones de Admisión a la Internacional Comunista, redactadas por Lenin y Zinoviev, no eran sino una versión renovada de las "Tesis de Heidelberg" pero "reforzadas un tanto en la dirección del centralismo y la dictadura" (citado por Bock 1969, p 255). Como resultado de la escisión, el $\mathrm{KPD}(\mathrm{S})$ perdió algo más de la mitad de sus 107,000 miembros (Gruber 1967, p. 395). Claramente, sería un error atribuir a Levi una noción superficial de "espontaneísmo luxemburguista."

Karl Radek había sostenido los mismos argumentos que Levi antes del Congreso de Heidelberg. Radek llamó a las ideas de la oposición "esa mescolanza de anarquismo y sindicalismo" (Radek 1919, p. 9), pero se opuso a la iniciativa de Levi de eliminar a la izquierda consejista anarco-sindicalista del $\operatorname{KPD}(\mathrm{S})$. Radek fue secundado en esto por Lenin, quien apoyó la retención del KAPD como "miembro simpatizante de la Internacional Comunista", aunque más tarde describiría esta decisión como un error (Lenin 1921c, p. 319). 


\section{El putsch de Kapp y los "nueve puntos de los sindicatos"}

(19 de marzo de 1920)

Entre el 13 y el 17 de marzo de 1920 tuvo lugar el putsch Kapp-Lüttwitz, un golpe militar desencadenado por la demanda del Tratado de Versalles de disolver a los Freikorps, especialmente los del Báltico, que habían luchado contra el Ejército Rojo y tomado Riga en mayo de 1919. El golpe fracasó debido a una huelga general declarada a iniciativa de Carl Legien, el eterno presidente de la federación de sindicatos socialdemócratas. Como resultado de la huelga general, Alemania se cubrió en marzo de 1920 de una red de "consejos ejecutivos" o "comités de acción" (Vollzugsräte) formados por los partidos obreros y los sindicatos. La lucha contra el golpe de estado llevó esos comités a desempeñar el papel de centros revolucionarios, planteando en forma práctica, en el transcurso de la propia huelga general, el problema del poder. El líder de la burocracia sindical socialdemócrata, Carl Legien, argumentó que existía una posibilidad inmediata de formar un gobierno obrero (reformista) con los representantes de los sindicatos y de los dos partidos socialdemócratas. Finalmente, ni el USPD ni el $\operatorname{KPD}(\mathrm{S})$ aprovecharon la oportunidad, y dicho gobierno no se formó.

En su historia de la revolución alemana, Pierre Broué ofrece una versión condensada de los "nueve puntos de los sindicatos", que Legien impuso como condición al gobierno para poner fin a la huelga general el 19 de marzo de 1920 (Broué 2005, p. 365). Esta es la versión completa, tomada de Die Kommunistische Internationale, el órgano en lengua alemana de la Internacional Comunista:

Los representantes aquí reunidos de los partidos de gobierno instarán a sus facciones parlamentarias a defender los siguientes principios:

1. En la formación inminente de los gobiernos en el Reich y en Prusia, el personal será seleccionado por los partidos de común acuerdo con las organizaciones sindicales de los trabajadores, empleados y funcionarios públicos que tomaron parte en la huelga general, y a dichas organizaciones se les concederá una influencia decisiva en la reorganización de la legislación económica y social, respetando los derechos del Parlamento.

2. Inmediata detención y castigo de todos los culpables del putsch o del derrocamiento de gobiernos constitucionales, así como de los funcionarios públicos que se pusieron a disposición de gobiernos ilegítimos.

3. Una limpieza a fondo de toda la administración pública, y de los consejos directivos de las empresas, de personalidades ligadas a la contrarrevolución, especialmente aquellos que desempeñan altos cargos, y su sustitución por personas de confianza. Reincorporación en el servicio público de todos los representantes de organizaciones perseguidos por su actividad política y sindical.

4. Aplicación inmediata de la reforma administrativa de manera democrática, con la participación de las organizaciones económicas de los trabajadores, empleados y funcionarios públicos.

5. Aplicación inmediata de las leyes existentes, y aprobación de otras nuevas, que garanticen a los obreros, empleados y funcionarios públicos la igualdad social y económica. Aprobación inmediata de una ley liberal de la función pública. 
Daniel Gaido, Paul Levi y los orígenes del comunismo alemán: el KPD y las raíces de la política de Frente Único (enero 1919-marzo 1921) / Paul Levi and the Origins of German Communism: the KPD and the Roots of the United Front Policy (January 1919-March 1921), Revista Izquierdas.cl, número 22, enero 2015, ISSN 0718-5049, Santiago de Chile, pp. 20-47

6. Comienzo inmediato de la socialización en todas las industrias maduras para ello, sobre la base de las decisiones de la Comisión de Socialización, en consulta con las asociaciones profesionales. Convocatoria inmediata de la Comisión de Socialización, y asunción del control de los consorcios del carbón y del potasio por el estado.

7. La requisa y, de ser necesario, la expropiación de todos los alimentos disponibles, y la intensificación de la lucha contra la usura y la especulación en las zonas rurales y urbanas, asegurando el cumplimiento de las obligaciones de entrega de alimentos mediante la creación de organizaciones de suministro y la imposición de sanciones drásticas a las violaciones maliciosas de dichas obligaciones.

8. Disolución de todas las formaciones militares contrarrevolucionarias que no se mantuvieron fieles a la Constitución y su sustitución por formaciones reclutadas entre los círculos de la población republicana fiable, en particular de los trabajadores organizados, de los empleados y de los funcionarios públicos, sin lesionar ningún estamento (Stand). Con esta reorganización, los derechos legales adquiridos por las tropas y fuerzas de seguridad que se mostraron leales permanecen intactos.

9. Dimisión de [los ministros] Noske y Heine, que ya han presentado sus solicitudes de renuncia (Spartacus 1921, p. 157).

La cuestión crucial, desde el punto de vista de los comunistas, era el armamento de los trabajadores y el desarme de la contrarrevolución, tal como se indica en el punto 8 de los "nueve puntos de los sindicatos".

Cuando el golpe de Kapp estalló, Levi cumplía una condena en la prisión de Moabit, de donde fue liberado el 24 de marzo de 1920. Durante su detención, se enteró de la posición de la Zentrale (la instancia dirigente del KPD, equivalente al Comité Político o Politburó) ante la declaración de la huelga general de los sindicatos y le envió una carta furiosa, publicada luego por el órgano oficial del Comité Ejecutivo de la Internacional Comunista, Die Kommunistische Internationale, en la que denunciaba el contenido de los volantes escritos por la dirección del KPD(S) el 13 de marzo de 1920:

Mi opinión: El Partido Comunista alemán está amenazado por una bancarrota moral y política. No puedo entender cómo alguien puede escribir en esta situación frases como la siguiente: "La clase obrera no es capaz de actuar en este momento. Hay que decirlo claramente". "Por el mero hecho de que el Lüttwitz y Kapp tomen el lugar de Bauer y de Noske, nada ha cambiado inmediatamente... en el estado de la lucha de clases"... Después de haber negado la capacidad de actuar de la clase obrera en el primer día, al día siguiente el partido saca un volante [que dice]: "Ahora, el proletariado alemán debe finalmente asumir la lucha por la dictadura del proletariado y la república comunista soviética". El volante luego habla de ... la huelga general (después de que la clase obrera había sido considerada incapaz de realizar una acción). Al mismo tiempo (cuando la huelga general había sacado a las masas de las fábricas) [el folleto pide la] elección de soviets [y la convocatoria a un] congreso soviético central. En resumen, nuestros "peces gordos" rompen el cuello de la huelga general, organizativamente y políticamente. También lo hacen moralmente. Considero que es un crimen romper ahora la acción al afirmar: "El proletariado no levantará un dedo por la república democrática". ¿Saben lo que eso significa? ¡Esta es una puñalada por la espalda a la mayor acción del proletariado alemán!... (Levi 1920a, pp. 147-148). 
Daniel Gaido, Paul Levi y los orígenes del comunismo alemán: el KPD y las raíces de la política de Frente Único (enero 1919-marzo 1921) / Paul Levi and the Origins of German Communism: the KPD and the Roots of the United Front Policy (January 1919-March 1921), Revista Izquierdas.cl, número 22, enero 2015, ISSN 0718-5049, Santiago de Chile, pp. 20-47

Levi procede luego a hacer algunas observaciones generales sumamente interesantes sobre la actitud a adoptar en esta clase de eventos, que traen reminiscencias de la actitud adoptada por los bolcheviques ante el intento de golpe del general Kornilov:

Yo siempre había pensado que estábamos de acuerdo en lo siguiente: si una acción estalla ¡incluso para el objetivo más estúpido! (la revolución de noviembre no tenía ningún objetivo razonable, o más bien ningún objetivo en absoluto) debemos defender esta acción, y elevarla por encima de dicho objetivo estúpido por medio de nuestras consignas, [de modo tal que] acerquemos a las masas al verdadero objetivo ¡a través de la intensificación de la acción! Y no afirmar desde el principio "no vamos a mover un dedo" si no nos gusta el objetivo. En el ínterin es necesario plantear consignas concretas. ¡Digan a las masas lo que debe suceder en el momento mismo! Las consignas deben, por supuesto, intensificarse, [pero] gradualmente. La república soviética viene al final, no al principio. La consigna en el momento actual sólo puede ser: el armamento del proletariado (Levi 1920a, p. 148).

En contra de la convicción metafísica de la Zentrale de que un gobierno socialdemócrata permanecería siempre igual a sí mismo, Levi indicaba que su carácter estaría determinado por las fuerzas sociales en las que se apoyaba:

Si, después de la supresión del propio golpe militar, tenemos de nuevo un gobierno Bauer-Ebert-Noske, ya no sería idéntico al anterior, porque habría perdido su apoyo a la derecha, así como no fue el mismo en enero de 1919, después de haber perdido el apoyo de la izquierda. ¡Por lo tanto, ahora es imperativo ante todo intensificar la acción para aplastar el golpe sin compromisos! Si tenemos éxito, cualquier futura "república democrática" se deslizará hacia la izquierda, porque perdería su apoyo a la derecha. ¡Sólo entonces llegará el momento en el que podemos desarrollarnos nosotros mismos! Ahora tenemos que emprender una acción conjunta - también con el SPD ... Consigna inmediata: ¡Ningún compromiso! [con los golpistas] (Levi 1920a, p. 148).

En una carta escrita el día siguiente, Levi precisaba esta consigna ("Inmediata detención de los líderes del golpe de Estado y su condena por un tribunal proletario, porque un tribunal militar [sería una] comedia"), agregando:

Lo que la Zentrale del KPD escribe en su folleto de 16 de marzo [1920] es inútil. "República Soviética" y "Congreso de los Soviets" no son demandas, mientras la gente no trabaje para su concreción... "¡Abajo la dictadura militar", "Abajo con la democracia burguesa", tampoco son demandas de la huelga, sino frases. ... ¡No debemos demandar la "dimisión" del gobierno Kapp sino su arresto! ¡Los traidores no "renuncian"! ¡El "desarme del ejército"! En este momento, esta demanda es un disparate, porque empuja a las unidades del ejército que están en contra del golpe de estado al campo contrario. Esa demanda se dirige contra una parte de las fuerzas con las que el proletariado debe contar en este momento. "Confiscación inmediata de las armas de la burguesía, formación de un ejército de la clase obrera": estas dos demandas no pueden ser satisfechas de la noche a la mañana, su implementación 
Daniel Gaido, Paul Levi y los orígenes del comunismo alemán: el KPD y las raíces de la política de Frente Único (enero 1919-marzo 1921) / Paul Levi and the Origins of German Communism: the KPD and the Roots of the United Front Policy (January 1919-March 1921), Revista Izquierdas.cl, número 22, enero 2015, ISSN 0718-5049, Santiago de Chile, pp. 20-47

necesita semanas - por lo tanto no pueden representar demandas de la huelga (Levi 1920a, p. 149).

Levi concluía su carta con una serie de indicaciones prácticas sobre las actividades que el partido debía realizar:

Una vez al día, o dos veces, dependiendo de la situación, un folleto general; no un "compendio comunista", sino cuatro frases sobre la situación, una frase conteniendo la conclusión, y las demandas de la huelga. En particular, [el folleto debe incluir] críticas a la dirección de la huelga, que va a querer llegar a un acuerdo [con los golpistas]. Un folleto para los soldados. Un folleto dirigido al SPD. Un folleto para los funcionarios públicos, escrito de manera explicativa. Un folleto para los trabajadores de los ferrocarriles, correos y telégrafos. 2. Intensificación de la acción. Reuniones de manifestaciones en el parque de Treptower [en Berlín], sin enfrentamientos armados. 3. Instrucción militar de los cuadros, pero sin armas. Cuando las tropas procedentes del exterior choquen con las tropas locales, la ciudad no debe permanecer en silencio (Levi 1920a, p. 150).

La publicación de esta carta, junto con otras críticas a la posición de la Zentrale escritas por Clara Zetkin, Ernst Meyer y Karl Radek, indica claramente que los líderes bolcheviques estaban dispuestos a adoptar una posición laxa ante violaciones de la disciplina partidaria con tal de combatir las tendencias sectarias. Este respaldo de la dirección de la Internacional Comunista a su lucha contra las tendencias de ultraizquierda en el KPD sin duda alentó a Paul Levi a dar su siguiente paso, que también generaría mucha resistencia dentro de su propio partido y de la propia Internacional.

\section{Paul Levi y la "Declaración de Oposición Leal” (23 de marzo 1920)}

A iniciativa de Levi, el KPD(S) publicó en Die Rote Fahne, el 26 de marzo de 1920, una declaración de "oposición leal" a un gobierno (reformista) de los trabajadores como el propuesto por Legien después del putsch de Kapp. La "Declaración de Oposición Leal" fue un primer, aunque tardío, intento de aplicar una consigna transicional central: el apoyo, en determinadas condiciones, a la creación de un gobierno de partidos y organizaciones obreras reformistas - una táctica que sería oficialmente adoptada por la Internacional Comunista en su cuarto congreso, celebrado en 1922 (Riddell 2011). Este documento, nunca antes traducido al castellano o al inglés, dice lo siguiente:

1. El golpe militar de Kapp-Lüttwitz significa el colapso de la coalición socialistaburguesa. ${ }^{2}$ La lucha del proletariado contra la dictadura militar fue una lucha contra la coalición socialista-burguesa y tuvo como propósito ampliar el poder político de la clase obrera hasta la completa eliminación de la burguesía.

\footnotetext{
${ }^{2}$ Una referencia al gobierno presidido por Gustav Bauer del SPD, una coalición del SPD, el Zentrum católico y liberal Deutsche Demokratische Partei (DDP). Dicho gobierno, conocido como el Kabinett Bauer, duró desde el 21 junio de 1919 hasta el 27 marzo de 1920. Cayó diez días después del colapso del putsch de Kapp y fue reemplazado por el primer gobierno presidido por Hermann Müller. El Kabinett Müller I fue también una coalición del SPD, el Partido del Centro y el DDP.
} 
Daniel Gaido, Paul Levi y los orígenes del comunismo alemán: el KPD y las raíces de la política de Frente Único (enero 1919-marzo 1921) / Paul Levi and the Origins of German Communism: the KPD and the Roots of the United Front Policy (January 1919-March 1921), Revista Izquierdas.cl, número 22, enero 2015, ISSN 0718-5049, Santiago de Chile, pp. 20-47

2. La dictadura proletaria puede erigirse sólo como una dictadura de los sectores cruciales del proletariado y requiere un fuerte Partido Comunista, apoyado por la conciencia revolucionaria de la población trabajadora, que se compromete abiertamente con la dictadura del proletariado.

3. La etapa actual de la lucha, en la que el proletariado todavía no dispone de suficiente poder militar, en la que el Partido Socialdemócrata de la mayoría [SPD] ${ }^{3}$ todavía tiene una fuerte influencia sobre los funcionarios, empleados y ciertos sectores de los trabajadores, en la que el USPD tiene detrás de sí a la mayoría de los obreros urbanos, es una indicación de que aún no existe la base objetiva para la dictadura del proletariado.

4. Para conseguir que las masas proletarias se adhieran a la causa del comunismo es un elemento de importancia inmensa, desde el punto de vista del desenvolvimiento de la dictadura del proletariado, que pueda ser utilizado ilimitadamente el estado de cosas creado por la libertad política y que la democracia burguesa no pueda manifestarse como dictadura del capital.

5. El Partido Comunista considera que la formación de un gobierno socialista del que estén excluidos los partidos capitalistas burgueses es una situación deseable para la autoafirmación de las masas proletarias y para su maduración para el ejercicio de la dictadura del proletariado. Actuará ante tal gobierno como una oposición leal, siempre que dicho gobierno otorgue garantías para la actividad política de la clase obrera, combata la contrarrevolución burguesa por todos los medios disponibles, y no inhiba el fortalecimiento social y organizativo de la clase obrera.

Por "oposición leal" entendemos: renuncia a la preparación de un derrocamiento violento, obviamente reteniendo la libertad de agitación política del partido para sus objetivos y consignas (Die Rote Fahne, 23. März 1920, reeditado en Spartakus 1920, p. 161).

Esta táctica fue luego rechazada por la Zentrale del $\mathrm{KPD}(\mathrm{S})$ por doce votos contra ocho, así como por Béla Kun y Nikolai Bujarin, pero recibió el respaldo crítico de Lenin en su opúsculo La enfermedad infantil del izquierdismo en el comunismo, escrito en abril de 1920. Lenin consideraba que la declaración era "completamente justa, tanto en lo que se refiere a las premisas fundamentales como desde el punto de vista de las conclusiones prácticas. Las premisas fundamentales se reducen a afirmar que, en el momento actual, no existe la 'base objetiva' para la dictadura del proletariado, pues la 'mayoría de los obreros urbanos' está por los independientes. Conclusión: promesa de una 'oposición leal' (es decir, renuncia a la preparación del 'derrocamiento por la fuerza') al gobierno 'socialista, con exclusión de los partidos capitalistas burgueses'.

Lenin consideraba que dicha táctica era "indudablemente justa en el fondo" pero precisaba que "no se puede llamar 'socialista' (en una declaración oficial del Partido Comunista) a un gobierno de social-traidores", como no se podía "hablar de la exclusión 'de los partidos capitalistas burgueses', cuando los partidos de los Scheidemann [el SPD] y los Kautsky-Crispien [el USPD] son partidos democráticos pequeñoburgueses". Pero sobre todo, Lenin consideraba erróneo el párrafo IV de la declaración, ya que consideraba imposible "que la democracia burguesa no pueda manifestarse como dictadura del capital". Según Lenin:

\footnotetext{
${ }^{3}$ El nombre que se utilizaba para diferenciarlo del Partido Socialdemócrata Independiente (USPD).
} 
Daniel Gaido, Paul Levi y los orígenes del comunismo alemán: el KPD y las raíces de la política de Frente Único (enero 1919-marzo 1921) / Paul Levi and the Origins of German Communism: the KPD and the Roots of the United Front Policy (January 1919-March 1921), Revista Izquierdas.cl, número 22, enero 2015,

ISSN 0718-5049, Santiago de Chile, pp. 20-47

Los caudillos pequeñoburgueses, los Henderson (los Scheidemann) y los Snowden (los Crispien) alemanes no salen ni pueden salirse del marco de la democracia burguesa, la cual, a su vez, no puede dejar de ser la dictadura del capital. De estas cosas, falsas en principio y perjudiciales políticamente, no había por qué hablar desde el punto de vista del resultado práctico que perseguía con toda justeza el Comité Central del Partido Comunista. Para ello bastaba decir (si se quería emplear la cortesía parlamentaria): mientras la mayoría de los obreros de las ciudades siga a los independientes, nosotros, los comunistas, no podemos impedir que estos obreros se libren de sus últimas ilusiones democráticas y pequeñoburguesas (es decir, "burguesas-capitalistas" también) a base de la experiencia de "su" gobierno. Esto es suficiente para justificar el compromiso, que es realmente necesario y que debe consistir en renunciar por cierto tiempo a toda tentativa de derribar por la fuerza a un gobierno que goza de la confianza de la mayoría de los obreros de las ciudades. Pero en la agitación cotidiana entre las masas, que no tiene por qué hacerse con la cortesía parlamentaria oficial, se podría, naturalmente, añadir: dejemos que esos canallas como Scheidemann, esos filisteos como los Kautsky-Crispien pongan de manifiesto con sus obras hasta qué punto están ellos mismos engañados y engañan a los obreros; su gobierno "puro" efectuará "mejor que nadie" el trabajo de "limpiar" los establos de Augías del socialismo, del social-democratismo y demás formas de la social-traición (Lenin 1920, pp. 118-120).

Los meses de marzo y abril 1920 fueron testigo de la lucha del así llamado "Ejército Rojo del Ruhr" (Rote Ruhrarmee) contra los Freikorps y el Ejército. El documento "La situación mundial y la revolución alemana" (Fernbach 2011, pp. 79-91) contiene la evaluación de Levi del putsch de Kapp. Levi criticó las acciones ultraizquierdistas del KPD durante el putsch de Kapp, tales como las guerrillas urbanas encabezadas por Max Hoelz y las acciones de sabotaje llevadas a cabo en Renania-Westfalia, pero sobre todo fue muy crítico con el abstencionismo y la pasividad de la Zentrale el 13 de marzo 1920, lo que privó al KPD(S) de una influencia real sobre los acontecimientos (Broué 2005, p. 388). La publicación por el órgano del Comité Ejecutivo de la Internacional Comunista, Die Kommunistische Internationale, de un informe de Paul Levi sobre la situación política alemana en septiembre de 1920 es una clara indicación de que este orgfanismo continuaba respaldándolo inmediatamente antes del Congreso de Halle del USPD (Levi 1920b).

\section{El Congreso de Halle (octubre de 1920) y la "Carta Abierta" del VKPD (enero de 1921)}

Del 12 al 17 de octubre de 1920, el USPD celebró un congreso en Halle que dio lugar a una escisión entre sus alas derecha e izquierda y al nacimiento del Partido Comunista Unificado de Alemania (Vereinigte Kommunistische Partei Deutschlands, VKPD), después de la unificación de la izquierda del USPD con la Liga Espartaquista en diciembre de 1920. En dicho congreso oraron no solamente los representantes de la democracia y del comunismo alemán, sino también Martov y Zinoviev, lo que da cuenta de la significación internacional del evento (ver los documentos en Lewis y Lih 2011). El resultado de la táctica implementada por Paul Levi fue la formación del partido comunista más grande del mundo 
fuera de las fronteras de Rusia: el VKPD llegó a tener 350.000 miembros antes de la "acción de marzo" de 1921.

En la "Carta Abierta" ("Offener Brief"), publicada el 8 de enero 1921 en el órgano del partido Die Rote Fahne, el VKPD propuso, a instancias de Paul Levi, a todas las organizaciones y partidos obreros llevar a cabo acciones conjuntas en los puntos en los que un acuerdo era posible. Como señala Broué, "la primera iniciativa importante en la dirección de la política que Levi esbozó vino de las filas obreras del VKPD”, más específicamente del sindicato metalúrgico de Stuttgart (Broué 2005, p. 468). Dada la importancia de la "Carta Abierta"-que básicamente era, en la terminología actual, una propuesta de plan de lucha dirigida a las otras organizaciones de la clase obrera- y el hecho de que dicho documento nunca fue traducido al castellano o al inglés, hemos incluido el texto completo como Apéndice al presente artículo.

La "Carta Abierta" fue la primera declaración pública de un partido comunista a favor de la táctica conocida más adelante como Einheitsfrontpolitik o "Política de Frente Único". A pesar de que la "Carta Abierta" fue rechazada por la dirección derechista de las organizaciones a las que iba dirigida, Lenin la llamó una "táctica perfectamente correcta", y añadió: "He condenado la opinión contraria de nuestra 'izquierdistas' que se oponían a esta carta" (Lenin 1921a). Lenin se expresó con mayor fuerza aun sobre este tema. En una carta a Zinoviev fechada el 10 de junio de 1921, escribió:

La táctica de la "Carta Abierta" sin duda se debe aplicar en todas partes. Esto debe ser dicho directamente, con claridad y exactitud, porque las vacilaciones en torno a la "Carta Abierta" son extremadamente nocivas, muy vergonzosas y muy extendidas. Todos aquellos que no han comprendido la necesidad de la táctica de la Carta Abierta deberían ser expulsados de la Internacional Comunista dentro de un mes después de su Tercer Congreso. Veo claramente mi error en la votación para la admisión de KAPD. Tendrá que ser rectificado tan rápida y completamente como sea posible (Lenin 1921c, p. 319).

La táctica de la "Carta Abierta" del 8 de enero de 1921 fue desarrollada más tarde en las "Tesis sobre la unidad del frente proletario", adoptadas por el Comité Ejecutivo de la Internacional Comunista en diciembre de 1921, luego refrendadas por la primera Sesión Plenaria Ampliada del Comité Ejecutivo de la Internacional Comunista, que se reunió en Moscú desde el 21 de febrero hasta el 4 de marzo de 1922 (Gruber 1967, pp. 362-371, ver también Trotsky 1922) y por el cuarto congreso de la Internacional Comunista celebrado en noviembre de 1922 (AA.VV., 1973, pp. 191-200).

\section{La escisión de Livorno (21 enero 1921) y la formación del Partido Comunista Italiano}

El 21 de enero 1921 tuvo lugar la escisión del Partido Socialista Italiano en el congreso celebrado en Livorno, de acuerdo con las 21 Condiciones de Admisión a la Internacional Comunista adoptadas por su II Congreso en 1920, y a iniciativa de dos enviados de la Comintern: el húngaro Mátyás Rákosi y el búlgaro Hristo Kabakchiev. El Congreso de Livorno del PSI dio lugar a la formación del Partido Comunista Italiano por el ala izquierda 
Daniel Gaido, Paul Levi y los orígenes del comunismo alemán: el KPD y las raíces de la política de Frente Único (enero 1919-marzo 1921) / Paul Levi and the Origins of German Communism: the KPD and the Roots of the United Front Policy (January 1919-March 1921), Revista Izquierdas.cl, número 22, enero 2015,

ISSN 0718-5049, Santiago de Chile, pp. 20-47

escindida, liderada por Amadeo Bordiga, una medida a la que Levi, que asistió al congreso y pronunció uno de los discursos de apertura ${ }^{4}$, se opuso, y que conduciría a su renuncia del Comité Central del VKPD. Levi rechazó, no la escisión en sí, sino la manera torpe y sectaria en la que fue llevada a cabo, es decir, mediante la expulsión, no sólo de la derecha dirigido por Filippo Turati, sino también del ala centrista liderada por Giacinto Serrati, que se llevó con él a la mayor parte del proletariado italiano organizado. Levi envió un informe a este respecto al Comité Ejecutivo de la Internacional Comunista. ${ }^{5}$

La posición de Levi merece un examen cuidadoso, ya que no se puede argumentar que era un hombre pusilánime que rehuía la perspectiva de cualquier escisión. De hecho, durante los cuatro años anteriores había tomado parte o había jugado un rol dirigente en cuatro escisiones: la ruptura del USPD del SPD en 1917, la escisión del KPD(S) del USPD en 1918, la expulsión de los ultraizquierdistas del $\mathrm{KPD}(\mathrm{S})$ en el Congreso de Heidelberg en 1919 (que dio lugar a la formación del KAPD) y, finalmente, la ruptura entre las alas izquierda y derecha del USPD en su Congreso de Halle en octubre de 1920, que dio lugar a la formación de la VKPD. ¿Cuál fue, entonces, el motivo del rechazo de Levi a la forma en que la escisión de Livorno se llevó a cabo?

"Estoy convencido de que el núcleo de la izquierda del USPD en Alemania es equivalente al grupo de Serrati", sostuvo Levi. "Creo que sería un grave error por parte de la Internacional Comunista empujar a ese núcleo a la derecha por terquedad y por la fuerza" (citado en Cyr 2012, p. 148). Levi fue crítico de la forma "mecánica" en el que la escisión de Livorno había sido llevada a cabo, lo que significaba que la Internacional Comunista no sólo tiró por la borda a Serrati, sino también a las masas que estaban detrás de él. Esto planteaba "la cuestión fundamental: ¿cómo vamos a proceder a la construcción de un partido comunista en Europa Occidental?” (Fernbach 2011, p. 103). Según Levi:

Una cosa debería estar clara: existen dos formas para lograr un mayor grado de experiencia comunista en estas masas relacionadas organizativamente con la Tercera Internacional. Una forma de llevar a cabo esta educación implica nuevas escisiones; la otra manera implica que entrenamos políticamente a las masas que han encontrado su camino hacia nosotros, experimentamos con ellos la época actual, la revolución, y de esta manera llegamos a una etapa superior, junto con las masas y dentro de ellas. [...] No quiero ocultar nada: la vieja diferencia entre Rosa Luxemburg y Lenin emerge aquí de nuevo, la vieja diferencia que implicaba una pregunta: ¿cómo se forman los partidos socialdemócratas, para usar la jerga de aquel entonces? La historia ha pronunciado la sentencia. Lenin tenía razón: los partidos socialistas y comunistas también se pueden crear a través del veto estricto de simpatizantes [antes de su incorporación como miembros plenos al partido] propuesto por él. En un momento de ilegalidad, Lenin produjo un buen partido por dichos medios y por el proceso mecánico de adición de un comunista a otro; y tal vez, camaradas, si nos enfrentáramos a un período de ilegalidad de diez años, también podría votar a favor

\footnotetext{
${ }^{4}$ Reproducido por Palmiro Togliatti, que hacía las veces de editor del periódico en ausencia de Grasmci, en L'ordine nuovo, 16 de enero de 1921 (Cammett 1967, p. 258, note 8).

5 "Il rapporto di Levi al Comitato Esecutivo dell'IC sul congresso di Livorno, scritto subito dopo il suo ritorno a Berlino, è riprodotto in The Comintern: Historical Highlights, Essays, Recollections, Documents, Edited by Milorad M. Drachkovitch and Branko Lazitch, Hoover Institution on War, Revolution, and Peace, Stanford University, Stanford, Calif., 1966, pp. 271-282." (Cortesi, 1999, p. 297).
} 
de este método. Pero nosotros no contamos con un período de diez años (Fernbach 2011, p. 106).

La Internacional Comunista había elevado al rango de principio la idea de crear partidos "no a través de un crecimiento orgánico con las masas, sino a través de escisiones deliberadas" (Fernbach 2011, p. 108). Levi creía que "las escisiones en un partido de masas [...] no pueden llevarse a cabo sobre la base de resoluciones, sino sólo sobre la base de la experiencia política" (Fernbach 2011, p. 109). Los debates debían girar en torno a cuestiones políticas, no organizacionales, con el fin de dar lugar a un proceso de educación política. Levi predijo que "si la Internacional Comunista funciona en Europa Occidental en términos de admisiones y expulsiones como un cañón de retroceso" experimentaría "el peor de los reveses" (Fernbach 2011, p. 108).

\section{Mátyás Rákosi y la renuncia de Paul Levi a la Zentrale del VKPD}

El artículo de Levi sobre la escisión de Livorno en Die Rote Fahne, el 22 de enero de 1921, dio lugar a una discusión pública con Karl Radek, que defendió la posición del Comité Ejecutivo de la Internacional Comunista en dicho periódico cuatro días más tarde, y se enfrentó personalmente con él en una reunión tormentosa de la Zentrale. Radek lo acusó de apoyar el centrista Serrati (quien, a su vez, "se negó a romper con la burocracia sindical reformista"), y de ayudarlo a "sabotear las resoluciones del II Congreso de la Internacional Comunista en cuya redacción el mismo Levi colaboró" (Radek 1921a, pp. 310, 312, énfasis en el original). Sin embargo, miembros prominentes de la Zentrale como Clara Zetkin y su copresidente Ernst Däumig apoyaron a Levi.

El 22 de febrero 1921 Mátyás Rákosi, el futuro "mejor discípulo de Stalin en Hungría”, haciendo escala en Berlín en su camino de Italia a Rusia, pronunció un discurso ante el Comité Central del Partido Comunista Alemán ${ }^{6}$ defendiendo la escisión de Livorno, y obtuvo el apoyo del Comité Central por una pequeña mayoría. Sintiéndose desautorizados Levi y Däumig renunciaron al Comité Central junto con Clara Zetkin, Otto Brass, Adolf Hoffmann y Curt Geyer (que estaba entonces en Moscú). Como resultado, Heinrich Brandler emergió como líder efectivo del Partido. Lenin, que valoraba mucho el juicio de Levi, rechazó sus críticas a la escisión de Livorno, considerando su posición política equivocada, pero sobre todo condenó su actitud como irresponsable:

Considero tu táctica respecto a Serrati errónea. Cualquier defensa o incluso semidefensa de Serrati fue un error. ¿¿iiPero renunciar al Comité Central!!?? ¡Ese, en todo caso, fue el error más grande! Si toleramos la práctica de que los miembros responsables del Comité Central se retiren de él cuando quedan en minoría, los partidos comunistas nunca se desarrollarán normalmente ni serán fuertes. En vez de

\footnotetext{
6 "El Comité Central o Zentralausschuss, integrado por delegados de cada uno de los veintiocho distritos del partido, era un nuevo órgano de liderazgo creado por el KPD a finales de 1920. A partir de entonces, las decisiones políticas importantes se tomaron en las reuniones conjuntas del Comité Central y la Zentrale, que se convirtió en un órgano ejecutivo. El Comité Central no sólo servía para vigilar a la Zentrale, sino que, dada su representación más amplia, también se convirtió en un caldo de cultivo para las facciones disidentes" (Gruber 1987, p. 313).
} 
renunciar, hubiera sido mejor discutir la cuestión controvertida varias veces conjuntamente con el Comité Ejecutivo [de la Internacional Comunista] (Lenin 1921a).

Ahora que los "Levitas", como Radek llamaba a los seguidores de Paul Levi, estaban excluidos de la dirección del partido, era posible implementar una estrategia basada en la "teoría de la ofensiva" entonces patrocinada en la Internacional Comunista por Zinoviev. Es en este espíritu que el Comité Ejecutivo de la Internacional Comunista envió a Berlín, a principios de marzo de 1921, a Béla Kun, József Pogány (quien jugaría más tarde un papel vergonzoso en el Partido Comunista estadounidense como John Pepper, ver Cannon 1962) y August Guralsky (un pseudónimo de Abraham Heifetz).

El 16 de marzo 1921 Otto Hörsing, el gobernador socialdemócrata de Sajonia, anunció la ocupación militar de la Sajonia prusiana a fin de detener la "anarquía". Oficialmente en respuesta a esta provocación, el Partido Comunista Unificado de Alemania lanzó, del 17 al 29 de marzo de 1921, la así llamada "Acción de Marzo", una serie de levantamientos fallidos organizados en el contexto de la crisis del comunismo de guerra y de la rebelión de Kronstadt en Rusia (7-17 marzo 1921).

\section{El Partido Comunista Unificado de Alemania y la “acción de marzo" de 1921}

La "acción de marzo" fue organizada por el delegado del Comité Ejecutivo de la Internacional Comunista Béla Kun. Clara Zetkin se reunió con Béla Kun el 10 de marzo de 1921, y salió tan alarmada por lo que él le dijo que advirtió a Levi, y a partir de entonces se negó a reunirse con Kun excepto en presencia de un testigo. Se rumoreaba que Kun estaba siguiendo las instrucciones de Zinoviev, quien estaba asustado por las dificultades internas de Rusia y quería "forzar" una crisis revolucionaria en Alemania a fin de impedir que los comunistas rusos tuvieran que hacer la retirada conocida como la Nueva Política Económica (NEP), aprobada definitivamente por el Décimo Congreso del Partido Comunista de Rusia en el marco de la revuelta de Kronstadt. Según Pierre Broué:

La gente en el entorno de Zinoviev decía abiertamente que, aunque no obtuvieran la victoria, grandes luchas del proletariado internacional permitirían a Rusia evitar tener que recurrir a la Nueva Política Económica. [...] Podemos considerar como plausible que los que apoyaron la estrategia de la "ofensiva" en la Internacional deseaban sinceramente romper a toda costa el aislamiento que condenó a los bolcheviques a la retirada estratégica costosa de la NEP, forzando, si era necesario, el desarrollo y acelerando artificialmente la velocidad de la revolución (Broué 2005, pp. 494, 532).

El levantamiento en Alemania fue provocada por el anuncio del Oberpräsident de la Sajonia prusiana, el socialdemócrata Otto Hörsing, de que tenía la intención de hacer ocupar por la policía varias zonas industriales, incluido el distrito minero de MansfeldEisleben, claramente con el fin de desarmar a los trabajadores (que habían mantenido sus armas después del putsch de Kapp) y para desmantelar un bastión comunista. Los líderes del VKPD en Halle, que incluía el área de Mansfeld, recibieron la orden de llamar a una huelga general tan pronto como la policía ocupara una fábrica, y preparar a la vez a la 
resistencia armada. La convocatoria a una huelga general fue emitida el 20 de marzo de 1921 como un ultimátum a los trabajadores no comunistas. Sin embargo, en la mañana del 22 de marzo la huelga era sólo parcial. Era evidente que la masa de los trabajadores no estaba siguiendo a la vanguardia comunista, y que por lo tanto las condiciones no estaban maduras para la organización de un levantamiento. Sin embargo, eso es exactamente lo que hicieron los líderes de la VKPD, con el apoyo de la KAPD (Béla Kun había organizado en Berlín un acuerdo de acción conjunta entre los dos partidos comunistas), con resultados desastrosos.

El 24 de marzo de 1921, los comunistas usaron todos los medios, incluida la fuerza, para tratar de provocar una huelga general. Grupos de activistas trataron de ocupar las fábricas por sorpresa con el fin de impedir la entrada de la gran masa de trabajadores no comunistas, a los que llamaban "rompehuelgas". Por otra parte, grupos de desempleados se enfrentaron a los trabajadores en su camino al trabajo o en las fábricas. El resultado general fue insignificante. Estimaciones pesimistas calculaban 200.000 huelguistas; los optimistas afirmaban que el número de huelguistas llegó al medio millón. En Berlín, la huelga fue prácticamente inexistente, y la demostración conjunta del VKPD y el KAPD ni siquiera atrajo a 4.000 personas, mientras que unas pocas semanas antes, en las elecciones al Landtag prusiano del 20 de febrero de 1921, el VKPD había recibido 200.000 votos. En contra de las órdenes de la Zentrale, los líderes comunistas de la cuenca del Ruhr dieron la señal para volver a trabajar, pero no fue hasta el 1 de abril de 1921 que un llamamiento de la Zentrale dio la orden de poner fin a la huelga.

Los días que siguieron a la derrota de la Acción de Marzo revelaron la magnitud del desastre que los líderes del VKPD habían infligido a su partido, el cual perdió 200.000 miembros en unas pocas semanas (el VKPD tenía alrededor de 350.000 miembros a principios de marzo de 1921, mientras que sólo 150.000 suscripciones fueron pagadas en agosto de 1921). Por otra parte, el partido fue temporalmente declarado ilegal, sus periódicos fueron prohibidos y sus dirigentes detenidos, entre ellos Brandler. "Poco después, el Tercer Congreso de la Internacional Comunista dio su veredicto sobre la 'acción de marzo,' en la que vio un 'paso adelante,' al mismo tiempo que condenaba la teoría de 'la ofensiva a toda costa' que sus partidarios habían propuesto” (Broué 1964).

\section{Paul Levi: Nuestro camino: Contra el putschismo (abril de 1921)}

Paul Levi ofreció una aguda crítica a la "acción de marzo" en el folleto Nuestro camino: Contra el putschismo (Unser Weg: Wider den Putschismus), escrito del 3 al 4 de abril de 1921, y en el discurso “¿Cuál es el crimen: La 'acción de marzo’ o su crítica?”, pronunciado en una sesión del Comité Central del Partido Comunista Unificado de Alemania celebrada el 4 de mayo de 1921.

La introducción al folleto de Levi Nuestro camino: Contra el putschismo muestra el tono agudo en el que su crítica a la actuación del VKPD, y al papel de la Internacional Comunista en la misma, fue formulada: "Se debe poner fin a los juegos irresponsables con la existencia de un partido, con las vidas y los destinos de sus miembros. Son los miembros del partido los que tendrán que ponerle fin, ya que los responsables todavía se niegan a ver lo que han hecho" (Fernbach 2011, pp. 119-120). 
Daniel Gaido, Paul Levi y los orígenes del comunismo alemán: el KPD y las raíces de la política de Frente Único (enero 1919-marzo 1921) / Paul Levi and the Origins of German Communism: the KPD and the Roots of the United Front Policy (January 1919-March 1921), Revista Izquierdas.cl, número 22, enero 2015,

ISSN 0718-5049, Santiago de Chile, pp. 20-47

Según Levi, el VKPD recibía alrededor de la quinta parte de los votos de los trabajadores, y sus miembros constituían aproximadamente 1 de cada 16 obreros organizados en sindicatos (o sea, el 6,25\% de los trabajadores sindicalizados). Fuera del centro de Alemania, donde el VKPD poseía una mayoría numérica, no había ningún distrito en Alemania donde tuviera esa mayoría, y no controlaba ninguno de los distritos esenciales, tales como Berlín o Renania-Westfalia, donde una acción de masas podía destruir al estado burgués de inmediato. Además, el VKPD no tenía un apoyo importante en el ejército (que había sido convertido en un ejército "profesional" por el tratado de Versalles) o entre los trabajadores de los ferrocarriles, $\mathrm{y}$, en general, su influencia era mucho mayor entre los desempleados que entre los trabajadores organizados en sindicatos. Estaba por lo tanto obligado a colaborar y trabajar en conjunto con el proletariado en general, y sólo podía actuar como una vanguardia si la propia clase obrera entraba en acción. Por último, el VKPD no tenía ningún apoyo significativo entre las clases medias, que tendían a reunirse detrás de los partidos y grupos armados de la derecha nacionalista. En esas circunstancias, Levi sostenía, era una locura organizar un levantamiento como el que el VKPD realizó en marzo de 1921 “Cuál debería ser la relación de los comunistas con las masas en una acción?", se preguntaba Levi.

Una acción que corresponde simplemente a las necesidades políticas del Partido Comunista, y no a las necesidades subjetivas de las masas proletarias, está condenada de antemano. Los comunistas no tienen la capacidad de actuar en lugar del proletariado, sin el proletariado, y en última instancia, incluso contra el proletariado, especialmente cuando todavía constituyen una minoría dentro del proletariado. Lo único que pueden hacer es crear situaciones, utilizando los medios políticos descritos anteriormente, en las que el proletariado vea la necesidad de la lucha y la lleve adelante, $y$, en estas luchas, los comunistas pueden entonces dirigir al proletariado con sus consignas (Fernbach 2011, p. 146).

Un ultimátum como el lanzado a los trabajadores no comunistas durante la "acción de marzo" (“¡El que no está con nosotros está contra nosotros!”) estaban completamente fuera de lugar. Die rote Fahne, bajo la autoridad de la Zentrale, había "declarado la guerra a los trabajadores al comienzo de la acción, como una forma de empujarlos a la acción. Y comenzó la guerra. Los desempleados fueron enviados con antelación como columnas de asalto. Ocuparon las puertas de las fábricas. Irrumpieron en las plantas, iniciaron incendios en algunos lugares, y trataron de expulsar a los trabajadores fuera de las instalaciones. Una guerra abierta estalló entre los comunistas y los trabajadores" (Fernbach 2011, p. 148). Según Levi, las "características anarquistas de este levantamiento de marzo", tales como "la lucha de los desocupados contra quienes tenían trabajo, la lucha de los comunistas contra los proletarios, la aparición del lumpen-proletariado, los ataques con dinamita", fueron todas consecuencias lógicas de esta errónea actitud básica.

Levi llegaba a la siguiente conclusión: "Todo esto caracteriza el movimiento de marzo como el mayor putsch bakuninista en la historia hasta la fecha. [....] Llamarlo blanquismo sería un insulto a Blanqui" (Fernbach 2011, p. 148). Levi sacó la siguiente conclusión política de esta debacle: "Nunca más en la historia del Partido Comunista debe suceder que los comunistas declaren la guerra a los trabajadores. [....] El Partido 
Comunista es sólo la vanguardia del proletariado, y no puede ser lanzado contra el proletariado; no puede marchar si ha perdido la conexión con la fuerza principal" (Fernbach 2011, p. 157, énfasis de Levi).

Levi culpó a los emisarios del Comité Ejecutivo de la Internacional Comunista en Alemania por el levantamiento. En una clara referencia a Zinoviev, argumentó que "algunos círculos del Comité Ejecutivo mostraron cierto recelo ante de la 'inactividad' del Partido alemán. Aparte de los graves errores cometidos por el Partido durante el golpe de Kapp, sin embargo, el Partido Comunista Alemán no podía ser acusado de fallas reales. Existía, pues, una presión fuerte sobre la Zentrale para emprender una acción ahora, inmediatamente y a cualquier precio" (Fernbach 2011, p. 138, énfasis de Levi). Levi rechazó la "teoría de la ofensiva" de Zinoviev y Bujarin, respaldada por el argumento de que la Rusia soviética se encontraba en un momento crítico y que existía una necesidad urgente de alivio desde el exterior.

Según Levi, era necesario acabar con "el sistema de agentes confidenciales" que había causado tanto daño en Italia y Alemania. Europa Occidental y Alemania se habían convertido en "un banco de pruebas para todo tipo de aprendices de estadista" como Mátyás Rákosi, plenipotenciario del Comité Ejecutivo de la Internacional Comunista en Livorno. "No tengo nada en contra de estos turquestanos," sostuvo Levi (en una referencia a Béla Kun, cuyas ejecuciones de presos blancos durante la guerra civil rusa habían enfurecido a Lenin, quien lo envió en una misión para el Turquestán), pero "harían menos daño con sus trucos en su propio país" (Fernbach 2011, p. 18).

Levi llamó al "método de enviar personas irresponsables, que más tarde pueden ser aprobadas o desautorizadas a voluntad", un "juego frívolo" que sería "fatal para la Tercera Internacional". Un efecto todavía más perjudicial del "sistema de delegados" era el "contacto directo y secreto entre estos delegados y los dirigentes de Moscú". Dichos delegados del Comité Ejecutivo de la Internacional Comunista "nunca trabajan con la Zentrale del país de que se trate, sino siempre a sus espaldas y, a menudo, incluso en contra de ella. Ellos encuentran personas en Moscú que les creen, otros no. Es un sistema que socava inevitablemente toda confianza para el trabajo mutuo entre ambas partes, el Comité Ejecutivo de la Internacional Comunista y los partidos afiliados. Estos camaradas son generalmente inadecuados para el liderazgo político, además de ser muy poco confiables. Todo esto conduce a la falta un verdadero centro de liderazgo político" (Fernbach 2011, p. 163, énfasis de Levi).

El lenguaje desmedido de Levi anunciaba ya su próxima separación de la Internacional Comunista: "El Comité Ejecutivo de la Internacional Comunista funciona más o menos como un Cheka proyectada más allá de las fronteras de Rusia - una situación imposible. La demanda de que esta situación cambie, y de que el liderazgo en ciertos países no debería ser asumido por delegados incompetentes, la exigencia de que exista un liderazgo político y no una policía partidaria, no es una reivindicación de autonomía" nacional (Fernbach 2011, p. 164). 


\section{Críticas adicionales de Levi al putschismo y su ruptura con la Internacional Comunista}

En su discurso en la reunión del Comité Central del VKPD del 4 de mayo de 1921 (llamado “¿Cuál es el crimen: La 'acción de marzo’ o su crítica?”) Levi desarrolló las ideas contenidas en su folleto Nuestro camino: Contra el putschismo. Comparó el desarrollo del comunismo en Rusia y Europa Occidental, arguyendo que, debido a las trayectorias históricas divergentes seguidas por ambas sociedades, éstas requerían diferentes formas de organización. Mientras que el bolchevismo se había desarrollado en una sociedad mayormente feudal, con una burguesía muy débil, en Europa Occidental "el proletariado se enfrenta a una burguesía totalmente desarrollada, y por ende a las consecuencias políticas del desarrollo de la burguesía, es decir, a la democracia, y, en democracia, o lo que se entiende como tal bajo el gobierno de la burguesía, la forma de organización de los trabajadores asume formas diferentes de las que asume bajo la forma estatal del feudalismo agrario, que es el absolutismo" (Fernbach 2011, pp. 182-183). En Europa Occidental la forma de organización sólo podía ser "la de un partido de masas que no está cerrado en sí mismo. Partidos de masas de este tipo nunca se pueden mover a las órdenes de un Comité Central, a las órdenes de una Zentrale, la única manera en que se pueden mover es en el fluido invisible en el que están situados, en la interacción psicológica con la totalidad de la masa proletaria fuera del partido" (Fernbach 2011, p. 183).

Había, además, otra diferencia fundamental: mientras que el marxismo en Rusia se había desarrollado en el seno de una clase trabajadora políticamente virgen, en Alemania y en Europa Occidental ya estaba organizada una gran parte del proletariado. Esto creaba la peligrosa posibilidad de una separación entre los trabajadores organizados, que permanecían unidos a los viejos partidos reformistas y a sus sindicatos, y los trabajadores no organizados o desempleados, que abrazaban el comunismo. En tal escenario, "el Partido Comunista no es lo que debería ser, la organización de una parte del proletariado -la parte más avanzada, pero una parte que atraviesa a todo el proletariado-, sino que se convierte en una parte del proletariado verticalmente dividida de acuerdo a aspectos socialmente diferenciadores" (Fernbach 2011, p. 183).

Alemania era, pues, una especie de laboratorio histórico en el que las tácticas necesarias para ganar a los proletarios agrupados en torno a las organizaciones de masas reformistas tenían que ser desarrolladas y probadas por primera vez. A fin de hacer esto, los comunistas tenían que llegar "en términos políticos a algún tipo de conexión con estas organizaciones", a fin de "ganar influencia política en ellas". El VKPD se había embarcado en este camino con la "Carta Abierta", que había planteado la consigna de la unidad debido a que "sólo es posible acercarse a las masas organizadas de los trabajadores, no simplemente luchando contra ellos, sino relacionándose con sus propias ideas, aun si éstas son erróneas, y ayudándoles a superar el error por su propia experiencia" (Fernbach 2011, p. 184).

Levi cerró su discurso denunciando los trucos sucios empleadas en la polémica en su contra, sobre todo por Radek: "Si alguien ha cometido un error, entonces debe atacar tres veces más a la persona que critica el error al tiempo que lo corrige en silencio. Es la táctica que utilizan para mantener su propia infalibilidad" (Fernbach 2011, p. 203). Levi denunció 
todos los intentos de llegar a un acuerdo privado, con el argumento de que "los errores de los comunistas son un componente de la experiencia política de la clase proletaria tanto como sus logros. Ni los unos ni los otros pueden o deben ser ocultados de las masas" (Fernbach 2011, p. 204).

En el Tercer Congreso de la Internacional Comunista, celebrado en junio-julio de 1921, Lenin y Trotsky se opondrían fuertemente a la "teoría de la ofensiva", pero mientras tanto, alentados por el respaldo de la Internacional Comunista a la "acción de marzo", la Zentrale votó, el 15 de abril de 1921, a favor de expulsar a Levi del Partido por indisciplina, y exigió que renunciara a su escaño como diputado en el Reichstag. Levi inmediatamente apeló al Comité Central contra la decisión de la Zentrale. El 16 de abril de 1921, ocho líderes de renombre y miembros responsables del partido declararon su solidaridad con él, y se ofrecieron como garantes de estaba diciendo la verdad: Ernst Däumig, Clara Zetkin, Otto Brass, Adolf Hoffman, que había dimitido con él de la Zentrale en febrero de 1921, Curt Geyer, el delegado del Partido en Moscú, y tres figuras centrales en la comisión sindical del partido, ex-dirigentes de los delegados revolucionarios (Revolutionäre Obleute), Paul Neumann, Heinrich Malzahn y Paul Eckert. Todo un sector de la dirigencia comunista alemana por lo tanto se negó a aceptar la expulsión de Levi o las razones aducidas para ello.

En una carta a Paul Levi y Clara Zetkin, fechada el 16 de abril de 1921, Lenin reconoció la veracidad de las críticas de Levi, declarando: "Estoy dispuesto a creer que el representante del Comité Ejecutivo [Béla Kun] defendió tácticas idiotas, demasiado izquierdistas - [tales como] tomar medidas inmediatas 'para ayudar a los rusos'. Este representante es muy a menudo demasiado izquierdista" (Lenin 1921a). Pero el intento de Lenin de llegar a un compromiso entre las fracciones del VKPD falló, y Levi abandonó el partido. Incluso tras la dimisión de Levi de la Internacional Comunista, Lenin argumentó que "esencialmente la mayor parte de las críticas de Levi a la acción de marzo en Alemania en 1921 eran correctas", aunque había "expresado su crítica en una forma inadmisible y perjudicial". "He defendido y tuve que defender a Levi, en la medida en que vi ante mí adversarios suyos que simplemente gritaban contra el 'menchevismo' y el 'centrismo' y se negaban a ver los errores de la acción de marzo y la necesidad de explicarlos y corregirlos” (Lenin 1921c, énfasis de Lenin).

\section{La "Asociación Comunista" (Kommunistische Arbeitsgemeinschaft) de 1921-1922}

El congreso del Partido Comunista de Alemania celebrado en Jena del 22 al 26 de agosto de 1921 expulsó a Curt y Anna Geyer, lo que precipitó la salida de tres diputados que habían estado hasta entonces indecisos, Ernst Däumig, Marie Mackwitz y Adolf Hoffmann, que se unieron a Levi para formar una efímera "Asociación Comunista" en el Reichstag (Kommunistische Arbeitsgemeinschaft, KAG). La ruptura fue una sangría severa para la representación parlamentaria del Partido Comunista alemán, porque Levi se llevó con él a la mayor parte de la delegación del Partido en el Reichstag.

Las demandas de la "Asociación Comunista" incluían cinco puntos que, además del rechazo al putschismo y a la interferencia externa irresponsable con los dirigentes de los 
partidos comunistas, subrayaban la hostilidad de Levi a la Internacional Sindical Roja (Profintern), establecida formalmente en julio de 1921. Éstos eran:

1) Independencia material completa de la Internacional Comunista;

2) Toda la literatura de las organizaciones comunistas extranjeras (incluidos los órganos de la Internacional Comunista y de la Internacional Sindical Roja) debe ser colocada bajo el control conjunto de los líderes del partido alemán;

3) Garantías contra todas las intervenciones organizacionales abiertas o encubiertas del Comité Ejecutivo de la Internacional Comunista junto con, fuera de o en contra de los órganos de la sección alemana;

4) Formulación en su programa de una política que haga posible la colaboración de todos los trabajadores revolucionarios de Alemania, renunciando expresamente a todos los intentos putschistas como el llevado a cabo durante la Acción de Marzo;

5) Formulación de una política sindical que, más allá de todos los objetivos revolucionarios, mantenga la unidad organizacional y la coherencia de los sindicatos alemanes (Fernbach 2011, p. 213).

El accionar subsecuente de Levi demostraría que este programa en realidad allanó el camino para su regreso a la Socialdemocracia.

\section{El alejamiento de Paul Levi del comunismo}

Después de romper con la Internacional Comunista, Levi giró cada vez más hacia la derecha y se mostró escéptico sobre las posibilidades de una nueva revolución. No obstante, una tercera ola revolucionaria comenzó en Alemania con la crisis generada por la ocupación francesa de la cuenca del Ruhr (11 de enero de 1923). La política de "resistencia pasiva" del gobierno llevó al colapso del marco. La hiperinflación, ya en marcha antes de la ocupación del Ruhr, alcanzó niveles inauditos hasta la introducción de una nueva moneda, el Rentenmark, el 16 de noviembre de 1923.

En octubre de 1923, el Partido Comunista formó un gobierno de coalición con el SPD en los estados de Turingia y Sajonia, bajo el lema del "frente único" de la izquierda. Los preparativos para la revolución incluyeron la formación de milicias conocidas como las Centurias Proletarias (Proletarischen Hundertschaften). Cuando el gobierno sajón ignoró las órdenes de Berlín de disolver las milicias y destituir a los ministros comunistas, el gobierno central envió al ejército a intervenir dichos estados. Esta así llamada Reichsexekution se llevó a cabo el 29 de octubre de 1923 en Sajonia y el 6 de noviembre de 1923 en Turingia. El líder del KPD, Heinrich Brandler, se negó a lanzar una insurrección después del fracaso de una iniciativa para convocar a una huelga general conjuntamente con las otras organizaciones. El fracaso del "Octubre alemán” (Deutscher Oktober) en 1923 fue la última convulsión revolucionaria de la república de Weimar, y abrió, con la ayuda de los préstamos estadounidenses canalizados a través del Plan Dawes, un período de estabilización económica y política que duraría hasta el estallido de la Gran Depresión, en octubre de 1929 (Bayerlein 2003). La revolución alemana fue, por lo tanto, en realidad una 
serie de crisis revolucionarias que abarcaron más de cinco años, desde noviembre de 1918 hasta octubre de 1923.

En cuanto a Paul Levi mismo, su progresivo alejamiento de la revolución rusa se manifestaría en su rechazo a la política de terror aplicada por los bolcheviques durante la guerra civil rusa, en su condena de la NEP como un regreso al capitalismo, en su visión del estalinismo como un producto natural del leninismo, en su camino de vuelta al redil socialdemócrata a través del USPD y en su adaptación gradual a la democracia parlamentaria burguesa (Fernbach 2011, pp. 227, 251, 279, 296-307).

\section{La valoración de David Fernbach sobre el accionar político de Paul Levi}

David Fernbach, el traductor de la versión estándar de los tres tomos de El Capital en inglés publicados por la editorial Penguin, ha prestado un servicio inestimable al estudio de la revolución alemana y de la Internacional Comunista al verter algunos de los principales escritos de Paul Levi, que previamente solo estaban disponibles en una antología en alemán (Beradt 1969), a la lingua franca de la ciencia. En su introducción a In the Steps of Rosa Luxemburg, Fernbach ofrece un buen resumen de la trayectoria política de Levi basado en Broué 2005, pero desde un punto de vista político peculiar. Según Fernbach, los partidos socialistas revolucionarios en el siglo XX se desviaron "de la revolución de la mayoría proletaria esperada por Marx [...] para tomar el poder sin un mandato electoral democrático", y la antología es sobre todo útil para "el estudio de la política de la revolución de la mayoría" (Fernbach 2011, p. 1).

Fernbach sostiene que Paul Levi "trató de continuar la política de Luxemburg de la revolución de la mayoría y consiguió convertir al KPD en un partido de masas de un tercio de millón de miembros" (Fernbach 2011, p. 2). Fernbach admite que "Rosa Luxemburg seguramente habría luchado más que Levi contra un retorno al SPD" (que se convirtió, recordémoslo, en un partido de gobierno en el marco de una sociedad capitalista), pero sostiene que ella "no podría haber escapado a la disyuntiva que Levi se planteó ya durante el putsch de Kapp: defender la República de Weimar o derrocarla". Fernbach concluye argumentando que "a medida que la amenaza del fascismo se intensificaba, los espartaquistas habrían tenido menos dificultades que los 'leninistas' en unirse con los socialdemócratas y los liberales en un 'compromiso histórico' que bien podría haber evitado la caída al abismo" (Fernbach 2011, p. 32).

Dado que no todos los lectores están familiarizados con los derroteros del estalinismo tardío (más conocido como eurocomunismo después de la publicación, en el año 1977, del libro del líder del Partido Comunista de España, Santiago Carrillo, titulado Eurocomunismo y Estado), nos tomaremos la libertad de realizar una breve digresión sobre la política de "compromiso histórico" del Partido Comunista de Italia.

En octubre de 1973, en una serie de artículos en Rinascita, el Secretario General del Partido Comunista de Italia, Enrico Berlinguer, propuso alcanzar un "compromiso histórico" entre los tres principales partidos políticos de la época, el PCI, la Democracia Cristiana y el Partido Socialista. Su punto de partida era la necesidad de evitar que se repitieran en Italia los acontecimientos recientes en Chile, donde el gobierno de Salvador Allende había sido derrocamiento por un golpe militar. Berlinguer sostenía que esta 
tendencia era evidente en Italia desde 1969. La militancia obrera y estudiantil había sido contrarrestada por la "estrategia de la tensión" de la extrema derecha, en el contexto de una situación económica en deterioro. Con el fin de oponerse a estas tendencias, Berlinguer propuso una nueva gran alianza, como la que las fuerzas anti-fascistas habían creado en el período 1943-1947 - es decir, un nuevo frente popular. Los demócratas cristianos nunca aceptaron la inclusión del PCI en el gobierno, prefiriendo a los socialistas por ser socios más flexibles, y Berlinguer abandonó el proyecto en noviembre de 1979, pero los años intermedios fueron testigo de los así llamados "gobiernos de solidaridad nacional" o "non sfiducia" ("no desconfianza") de Giulio Andreotti, basados en la abstención de los partidos de la oposición en los votos de desconfianza al gobierno. En otras palabras, los comunistas no fueron parte de la coalición gobernante, pero acordaron no provocar su caída. Según el historiador principal de la Italia de posguerra, Paul Ginsborg, "el 'cambio profundo en las estructuras económicas y sociales' que Enrico Berlinguer había previsto como una consecuencia del 'compromiso histórico' simplemente no existió en las reformas de los años 1976-8” (Ginsborg 2003, p. 394). De hecho, "la cooperación Andreotti-Berlinguer tenía paralelismos desconcertantes con la cooperación entre De Gasperi y Togliatti (no en vano Andreotti había sido subsecretario de De Gasperi). En ambas ocasiones, los comunistas tenían la difícil tarea de tratar de introducir reformas desde una posición subordinada; pero en ambas ocasiones se dejaron engañar por las maquinaciones políticas de sus oponentes" (Ginsborg 2003, p. 400). Perry Anderson llegó a la misma conclusión sobre la base de los resultados electorales: "Cuando se produjeron las elecciones en 1979, el PCI ha perdido un millón y medio de votos, y estaba de nuevo en la estacada. El PCI no había obtenido nada con el compromiso histórico, aparte de la desilusión de sus votantes y un debilitamiento de su base" (Anderson 2009, p. 337).

Así, el "compromiso histórico" italiano no tiene nada que mostrar en términos de logros reales, y de hecho sólo representó una etapa en la transformación de los partidos estalinistas de Europa Occidental en partidos reformistas. Es, por ende, al menos arriesgado afirmar, como lo hace Fernbach, que Rosa Luxemburg habría optado por semejante curso de acción, tal como lo hizo Levi.

\section{Conclusión}

Nuestra reseña de la trayectoria política de Paul Levi sugiere una valoración distinta a la ofrecida por David Fernbach. En nuestra opinión, Levi fue un estratega político talentoso, obligado en contra de su voluntad a asumir un rol histórico para el que no estaba preparado teóricamente y para el que no tenía el temperamento adecuado. Levi jugó un papel destacado como líder comunista en Alemania durante un par de años, hasta que decidió romper con la Internacional Comunista. Según Trotsky: "Durante las conferencias íntimas sobre los acontecimientos de marzo de 1921 en Alemania, Lenin dijo sobre Levi: 'Este hombre ha perdido completamente la cabeza'. 'Es cierto', Lenin añadió inmediatamente con picardía, 'que él, al menos, tenía algo que perder, cosa que no puede decirse de los otros" (Trotsky 1932, p. 103).

La eventual deriva política de Levi hacia la Socialdemocracia no absuelve, sin embargo, a la Internacional Comunista, de su responsabilidad por esa catástrofe que fue la 
"acción de marzo" de 1921. Primero, por haber permitido a Zinoviev y a Bujarin desarrollar en su seno la "teoría de la ofensiva" ultraizquierdista, cuya culminación lógica fue el putsch de marzo en Alemania. ${ }^{7}$ Segundo, por enviar a Mátyás Rákosi -en palabras de Pierre Broué, "una de las personas más limitadas y más brutales que jamás haya producido el movimiento comunista" - a hacer estragos en Livorno y luego en Berlín, forzando la dimisión de Paul Levi, Ernst Däumig, Clara Zetkin, Otto Brass, Adolf Hoffmann y Curt Geyer del Comité Central del Partido Comunista Unificado de Alemania. Tercero, por haber permitido a Karl Radek formar una fracción anti-Levi dentro del KPD, que incluía a Paul Fröhlich, August Thalheimer, Walter Stöcker y a la persona que reemplazaría a Levi al frente de la dirección del partido luego de la intervención de Rákosi, Heinrich Brandler. Cuarto, por haber enviado a otra persona limitada y brutal, Béla Kun, y a un aventurero político como József Pogány, a organizar el golpe de estado en Alemania. Y finalmente, por la manera en que la Internacional Comunista evitó hacer un balance serio de la desastrosa experiencia alemana.

Las "Tesis sobre la táctica" adoptadas por el tercer congreso de la Internacional Comunista dicen textualmente: "El $3^{\circ}$ congreso de la Internacional Comunista considera la acción de marzo del Partido Comunista Unificado de Alemania como un paso hacia adelante" (AA.VV. 1973, p. 51). Esto se escribió, recordémoslo, luego de un intento de golpe de estado, llevado a cabo contra la voluntad de la mayoría de la clase obrera alemana, como consecuencia del cual la Internacional Comunista perdió 200.000 militantes obreros en el corazón industrial de Europa en el transcurso de unas pocas semanas. La "Resolución sobre la acción de marzo y sobre el Partido Comunista Unificado de Alemania", adoptada por el mismo congreso, a su vez afirma:

El 3er. Congreso mundial comprueba con satisfacción que las resoluciones más importantes y particularmente el fragmento de la resolución sobre la táctica concerniente a la ardientemente discutida acción de marzo, han sido adoptadas por unanimidad y que hasta los representantes de la oposición alemana, en su resolución sobre la acción de marzo, se ubicaron de hecho en un terreno idéntico al del Congreso....

El Congreso solicita a la antigua oposición que disuelva inmediatamente toda organización de fracción, que subordine absoluta y totalmente su fracción parlamentaria a la Dirección Central, que supedite por entero la prensa a las organizaciones respectivas del Partido, que suspenda inmediatamente toda colaboración (en revistas, etc.) con Paul Levi, expulsado del Partido y de la Internacional Comunista (AA.VV. 1973, p. 106).

¿Por qué el congreso adoptó esta actitud? Recordemos que durante el putsch de Kapp, el Comité Ejecutivo de la Internacional Comunista publicó en su órgano oficial, Die Kommunistische Internationale, la furiosa carta que Paul Levi dirigió a la Zentrale del KPD desde la prisión de Moabit (la cual constituyó una falta de disciplina no menos grave que la

\footnotetext{
7 "La surestimation des états d'esprit « nationaux » de la classe ouvrière correspond au cri des opportunistes sur les insurrections dites prématurées" (Boukharine 1920, p. 220).

8 "Râkosi était l'un des plus bornés et des plus brutaux individus qu'ait jamais produit le mouvement communiste" (Broué 1997, p. 207).
} 
Daniel Gaido, Paul Levi y los orígenes del comunismo alemán: el KPD y las raíces de la política de Frente Único (enero 1919-marzo 1921) / Paul Levi and the Origins of German Communism: the KPD and the Roots of the United Front Policy (January 1919-March 1921), Revista Izquierdas.cl, número 22, enero 2015, ISSN 0718-5049, Santiago de Chile, pp. 20-47

publicación del folleto Nuestro camino: Contra el putschismo), acompañándola con una nota que rezaba:

Nuestros enemigos, naturalmente, habrán de alborozarse por los desacuerdos dentro del KPD. ¡Allá ellos! Nosotros, los comunistas, nunca hemos temido a la autocrítica. Los editores de Die Kommunistische Internationale están de acuerdo con la idea central de la crítica contenida en las tres cartas [el número incluía también cartas de Clara Zetkin y Ernst Meyer] y en el artículo del camarada Radek reproducido después de ellas (Levi 1920a, p. 147).

La cuestión de la disciplina era, entonces, secundaria. El secreto de la negativa de la Internacional Comunista a hacer un balance crítico de la "acción de marzo" está en la adopción de las resoluciones "por unanimidad", es decir, en el marco de un compromiso entre las fracciones existentes en el seno de la Internacional Comunista. Mientras que la posición sectaria adoptada por el KPD durante el putsch de Kapp había sido responsabilidad exclusiva de la Zentrale, toda la dirección de la Internacional Comunista estaba comprometida con la "acción de marzo", por lo que un balance serio de la misma hubiera implicado limpiar los establos de Augías de la Internacional. Esto hubiera tenido un efecto devastador sobre la reputación y la autoridad de personajes como Zinoviev, Bujarin, Karl Radek, Béla Kun y Mátyás Rákosi, los cuales, a su vez, tenían el apoyo de secciones nacionales importantes como la italiana. Dado el efecto disruptivo que esto habría tenido sobre al Internacional, Lenin y Trotsky consideraron que el mal menor era rescatar la táctica del frente único (el slogan adoptada por el tercer congreso fue "¡A las masas!", indicando la necesidad de conquistar una mayoría de las masas trabajadoras antes de contemplar la conquista del poder político), aun a precio de sacrificar a quien la desarrolló originalmente.

Es dable preguntarse si este compromiso fue una decisión acertada, dada la señal que envió a los militantes comunistas: las personas obedientes a las directivas de Moscú, aun si éstas eran dañinas para los intereses de la clase obrera, fueron premiadas, mientras que los críticos fueron denostados y expulsados (Zinoviev más tarde sistematizaría esta práctica en el marco de la política conocida como "bolchevización", que condujo a la expulsión de los partidarios de Trotsky de la Internacional Comunista y de sus secciones nacionales). Más aún, la nueva dirección del Partido Comunista alemán, consolidada al precio de semejante sacrificio, probaría no estar a la altura de las circunstancias cuando la historia le ofreció una segunda oportunidad, en octubre de 1923 (Bayerlein 2003). De todas maneras, los elementos positivos de la experiencia alemana quedaron plasmados en dos resoluciones adoptadas por el cuarto congreso de la Internacional Comunista: las "Tesis sobre la unidad del frente proletario" (AA.VV. 1973, pp. 191-200), válidas para los países imperialistas, y las "Tesis generales sobre la cuestión de Oriente", cuya sección sexta indica la táctica a seguir en los países semicoloniales, el "frente antiimperialista único" (AA.VV. 1973, pp. 231-233).

Recibido: 5 junio 2014

Aceptado: 2 octubre 2014 


\section{Bibliografía}

Anderson, Perry 2009, The New Old World, London: Verso.

AA.VV. 1973, Los cuatro primeros congresos de la Internacional Comunista: Segunda Parte, Buenos Aires: Ediciones Pasado y Presente.

Bayerlein, Bernhard (ed.), Deutscher Oktober 1923: Ein Revolutionsplan und sein Scheitern, Berlin: Aufbau Verlag, 2003.

Beradt, Charlotte (hrsg.) 1969, Zwischen Spartakus und Sozialdemokratie, Frankfurt: Europäische Verlagsanstalt.

Boukharine, N.I. 1920, « De la tactique offensive », Bulletin communiste, numéro 14 (deuxième année), 7 avril 1921, pp. 219-220. Original «O natupitel'noj taktike», Kommunistitcheskii Internasional, ${ }^{\circ} 15,1920$, col. 3073-3075.

Broué, Pierre 1973, Revolución en Alemania, Barcelona: A. Redondo.

Broué, Pierre 1997, Histoire de l'Internationale Communiste, 1919-1943, Paris: Fayard.

Broué, Pierre 2005, The German Revolution 1917-1923, Leiden: Brill.

Broué, Pierre 1964, "Germany 1921: The March Action," Fourth International, Volume 1, Number 2, Summer.

Cammett, John McKay 1967, Antonio Gramsci and the Origins of Italian Communism, Stanford University Press.

Cannon, James 1962, The First Ten Years of American Communism: Report of a Participant, New York: Little Stuart.

Claudín, Fernando, La crisis del movimiento comunista, París: Ruedo Ibérico, 1978.

Cortesi, Luigi 1999, Le origini del PCI: studi e interventi sulla storia del comunismo in Italia, Milano: Franco Angeli.

Cyr, Frédérique 2011, Rebelle devant les extrêmes: Paul Levi, une biographie politique (Thèse de doctorat, Université de Montréal).

Fernbach, David (ed.) 2011, In the Steps of Rosa Luxemburg: Selected Writings of Paul Levi, Leiden: Brill.

Ginsborg, Paul 2003, A History of Contemporary Italy: Society and Politics, 1943-1988, London: Palgrave Macmillan.

Gruber, Helmut (ed.) 1967, International Communism in the Era of Lenin: A Documentary History, Greenwich, Conn.: Fawcett Publications.

KPD [Kommunistische Partei Deutschlands] 1919, Bericht über den 2. Parteitag der Kommunistischen Partei Deutschlands (Spartakusbund) vom 20. bis 24. Oktober 1919, herausgegeben von der Kommunistischen Partei Deutschlands (Spartakusbund), Berlin.

Lenin, V.I. 1920, La enfermedad infantil del izquierdismo en el comunismo (abril 1920), Pekín: Ediciones en lenguas extranjeras, 1975.

Lenin, V.I. 1921a, "Letter to Clara Zetkin and Paul Levi" (16 April 1921), in Lenin, Collected Works, Moscow: Progress Publishers, 1976, Vol. 45, pp. 124-5.

Lenin, V.I. 1921b, "Remarks on the Draft Theses on Tactics for the Third Congress of the Communist International: Letter to G.Y. Zinoviev" (10 June 1921), in Lenin, Collected Works, Moscow: Progress Publishers, 1977, Vol. 42, p. 319. 
Lenin, V.I. 1921c, "A Letter to the German Communists" (14 August 1921), in Lenin, Collected Works, Moscow: Progress Publishers, 1965, Vol. 32, pp. 512-523.

Levi, Paul 1920a, "Brief an das Zentralkomitee der Kommunistischen Partei Deutschlands" (16 März 1920), Die Kommunistische Internationale. Organ des Executivkomitees der Kommunistischen Internationale, 2. Jg. 1920, Nr. 12, pp. 147-150.

Levi, Paul 1920b, "Die politische Lage in Deutschland" (September 1920), Kommunistische Internationale. Organ des Executivkomitees der Kommunistischen Internationale, 2. Jg., 1920, Nr. 14, pp. 114-125.

Lewis, Ben and Lars T. Lih 2011, Martov and Zinoviev: Head to head in Halle, London: November Publications.

Radek, Karl 1919, Zur Taktik des Kommunismus: Ein Schreiben an den Oktober-Parteitag der K.P.D., Berlin: Kommunistische Partei Deutschlands (Spartakusbund).

Radek, Karl 1921a, "The Italian Question" (original title: Soll die Vereinigte Kommunistische Partei Deutschlands eine Massenpartei der revolutionären Aktion oder eine zentristische Partei des Wartens sein?) in Gruber 1967, pp. 309-312.

Riddell, John (ed.) 2011, Toward the United Front: Proceedings of the Fourth Congress of the Communist International, 1922, Leiden: Brill.

Rosmer, Alfred 1972, Moscow under Lenin, New York: Monthly Review Press.

Spartakus 1920, "Der Kapp-Lüttwitz-Putsch (Brief aus Deutschland) (Berlin, April 1921)," Die Kommunistische Internationale, No. 10, Zweiter Jahrgang, pp. 147-171.

Trotsky, León 1922, Las tácticas del Frente Único: Escrito en marzo de 1922 para el Pleno del Comité Ejecutivo de la Internacional Comunista, Buenos Aires: Ediciones Cepe, 1973.

Trotsky, Leon 1932, What Next? Vital Questions for the German Proletariat, New York: Pioneer Publishers.

Weber, Hermann (hrsg.) 1967, Völker hört die Signale: Der deutsche Kommunismus 19161966, München: Deutscher Taschenbuch Verlag.

Weber, Hermann (Hrsg.) 1969, Der Gründungsparteitag der KPD: Protokoll und Materialien, Frankfurt: Europäische Verlagsanstalt.

Weber, Hermann (Hrsg.) 1973, Der deutsche Kommunismus: Dokumente 1915-1945, Köln: Kiepenheuer \& Witsch.

Apéndice: Carta abierta de la Zentrale del Partido Comunista Unificado de Alemania, 8 de enero de 1921

Fuente: "Offener Brief der Zentrale der Vereinigten Kommunistischen Partei Deutschlands", Die Rote Fahne (Berlin), 8. Januar 1921. Reproducido en Hermann Weber (hrsg.), Der deutsche Kommunismus: Dokumente 1915-1945, Köln: Kiepenheuer \& Witsch, 1973, pp. 168-169.

Carta abierta de la Zentrale del VKPD a la Federación General de Sindicatos Alemanes, la Asociación de las Ligas de Empleados Socialdemócratas, la Unión General de Trabajadores, el Sindicato de Trabajadores Libres (sindicalista), el Partido Socialdemócrata de Alemania, el Partido Socialdemócrata Independiente de Alemania, y el Partido Comunista Obrero de Alemania: 
Daniel Gaido, Paul Levi y los orígenes del comunismo alemán: el KPD y las raíces de la política de Frente Único (enero 1919-marzo 1921) / Paul Levi and the Origins of German Communism: the KPD and the Roots of the United Front Policy (January 1919-March 1921), Revista Izquierdas.cl, número 22, enero 2015,

ISSN 0718-5049, Santiago de Chile, pp. 20-47

El Partido Comunista Unificado de Alemania considera que es su deber, en este momento grave y difícil para todo el proletariado alemán, apelar a todos de los partidos y sindicatos socialistas.

La descomposición progresiva del capitalismo, las repercusiones de la crisis mundial incipiente sobre los efectos de la crisis alemana especial, la devaluación creciente de la moneda y el progresivo aumento en el precio de todos los alimentos y bienes de consumo, el aumento del desempleo y el empobrecimiento de las masas, todos los cuales continúan avanzando en Alemania, hacen necesario que la clase proletaria en su conjunto se defienda a sí misma, no sólo el proletariado industrial sino todas las capas que recién ahora despiertan [a la vida política] y toman conciencia de su carácter proletario. El proletariado es mantenido en esta situación insoportable por la reacción creciente, que especula con su falta de unidad y le impone siempre nuevas trabas a través de la Orgesch ${ }^{9}$, de los asesinatos, del poder judicial que encubre a todos los asesinos.

Por lo tanto, el VKPD propone que todos los partidos socialistas y las organizaciones sindicales se reúnan sobre las bases siguientes, dejando para más adelante la discusión detallada de las acciones individuales a realizar:

I.

a) Introducción de luchas salariales uniformes para asegurar la existencia de los trabajadores, empleados y funcionarios públicos. Combinación de las luchas salariales individuales de los trabajadores ferroviarios, los funcionarios públicos, los mineros y otros trabajadores industriales y agrícolas en una lucha única conjunta.

b) Aumento de todas las pensiones de las víctimas de guerra, los jubilados y pensionados en proporción a los aumentos de sueldos demandados.

c) Regulación uniforme del seguro de desempleo para todo el país, en base a los ingresos de los empleados a tiempo completo. Todo el costo de esta operación debe ser afrontado por el estado federal (Reich), que debe imponer impuestos solamente al capital para dicho propósito. Dicha operación debe controlada por los desempleados a través de los consejos especiales de desempleados, conjuntamente con los sindicatos.

II. Medidas para reducir el costo de vida, a saber:

a) Entrega de alimentos subsidiados a todos los asalariados y a quienes perciben estipendios bajos (pensionistas, viudas, huérfanos, etc.) bajo la supervisión de las cooperativas de consumo y el control de los sindicatos y comités de empresa. Los medios [financieros] necesarios deben ser proporcionados por el estado federal.

b) Confiscación inmediata de todos los cuartos habitables disponibles, con derecho no sólo a la ocupación compulsiva, sino también al desalojo forzoso de las familias pequeñas de apartamentos y casas de gran tamaño.

III. Medidas para la provisión de alimentos y bienes de consumo:

a) Control de todas las materias primas existentes, carbón y fertilizantes por parte de los consejos de trabajadores. Puesta en funcionamiento de todas las fábricas productoras de bienes de consumo que se encuentren paradas, distribución de los bienes así producidos de acuerdo con los principios detallados en II. a).

b) Control del cultivo, la cosecha y la venta de todos los productos agrícolas por los consejos de pequeños campesinos y los consejos rurales (Gutsräte), conjuntamente con las organizaciones de trabajadores agrícolas.

IV.

a) Desarme inmediato y disolución de todas las milicias burguesas, y creación de organizaciones de autodefensa proletarias en todos los estados (Länder) y comunidades.

${ }^{9}$ La "Orgesch" (una abreviación de "Organización Escherich", así llamada por el político de derecha Georg Escherich, un líder del Bayerische Volkspartei) fue un grupo paramilitar anticomunista y antisemita que operó en Baviera en 1920-1921. 
Daniel Gaido, Paul Levi y los orígenes del comunismo alemán: el KPD y las raíces de la política de Frente Único (enero 1919-marzo 1921) / Paul Levi and the Origins of German Communism: the KPD and the Roots of the United Front Policy (January 1919-March 1921), Revista Izquierdas.cl, número 22, enero 2015, ISSN 0718-5049, Santiago de Chile, pp. 20-47

b) Amnistía para todos los delitos cometidos por razones políticas o por causa de la pobreza general existente. Liberación de todos los presos políticos.

c) Supresión de las prohibiciones de huelga imperantes.

d) Establecimiento inmediato de relaciones comerciales y diplomáticas con la Rusia soviética.

Al proponer estas bases para la acción, no ocultamos en ningún momento, ni a nosotros mismos ni a las masas trabajadoras, que estas demandas que planteamos no pueden eliminar la pobreza. Sin sacrificar por un momento nuestra lucha por inculcar en las masas trabajadoras la idea de la lucha por la dictadura [del proletariado], el único camino a la salvación, sin dejar de pedir a las masas trabajadoras en cada momento oportuno que estén dispuestas a la lucha por la dictadura y $\sin$ renunciar al liderazgo de la misma, el Partido Comunista Unido está dispuesto a trabajar con los otros partidos obreros para emprender conjuntamente acciones que conduzcan a la consecución de las medidas mencionadas anteriormente.

No ocultamos las diferencias que nos separan de dichos partidos.

Declaramos, por el contrario: exigimos a las organizaciones a las que apelamos no comprometerse sólo verbalmente a las bases de acción propuestas, sino llevar adelante las acciones necesarias para conseguirlas.

Preguntamos a los partidos a las que nos dirigimos: ¿Consideran que estas demandas son correctas? Suponemos que lo hacen.

Les preguntamos: ¿Están ustedes dispuesto a emprender con nosotros una lucha sin cuartel para la consecución de estas demandas?

A esta pregunta clara y sin ambigüedades, esperamos una respuesta igualmente clara y sin ambigüedades. La situación requiere una respuesta rápida. Por lo tanto, esperamos una respuesta hasta el 13 de enero 1921.

En caso de que los partidos y los sindicatos a los que nos dirigimos no estén dispuestos a asumir la lucha, el VKPD se considerará obligado a librar esta batalla solo, y está convencido de que las masas trabajadoras lo seguirán. Hoy el VKPD invita a todas las organizaciones proletarias del país, y a las masas trabajadoras que las apoyan, a expresar su voluntad para la defensa común contra el capitalismo y contra la reacción, para la defensa común de sus intereses.

Zentrale (dirección) del Partido Comunista Unificado de Alemania 